\title{
Korespondencija između Dominika Mandića i Josipa Hamma u Arhivu Hercegovačke franjevačke provincije
}

Marina Beus

Sveučilište u Mostaru

Filozofski fakultet

E-pošta: marina.beus@ff.sum.ba

Dijana Korać

Sveučilište u Mostaru

Filozofski fakultet

E-pošta: dijana.korac@ff.sum.ba
UDK: 94(497.6)(044)"1951/1965"

929 Mandić D.

929 Hamm J.

Pregledni rad

Primljeno: 26. siječnja 2019.

Prihvaćeno: 9. travnja 2019.

\section{Sažetak}

U rukopisnoj ostavštini jednog od najpoznatijih hercegovačkih franjevaca, povjesničara Dominika Mandića nalazi se i njegova korespondencija s uglednim hrvatskim slavistom Josipom Hammom, a koja je nastala u razdoblju od 1951. do 1965. godine. Sadržaj ove korespondencije daje uvid u njihovu suradnju u znanstveno-istraživačkome radu, te donosi promišljanja ove dvojice znanstvenika o pojedinim temama koje su bile predmet zajedničkoga znanstvenog interesa. U pismima se također spominju imena nekih tadašnjih uglednih znanstvenika ali i neki segmenti iz njihova privatnoga života.

Ključne riječi: Dominik Mandić; Josip Hamm; korespondencija; znanstvena istraživanja. 
Marina Beus - Dijana Korać - Korespondencija...

\section{Uvod}

U rukopisnoj ostavštini fra Dominika Mandića (1889. - 1973.), ${ }^{1}$ koja se nalazi u Arhivu Hercegovačke franjevačke provincije, ${ }^{2}$ čuvaju se pisma, razglednice i telegrami koje su u drugoj polovici 20. stoljeća izmijenili ovaj poznati hercegovački franjevac i povjesničar s uglednim hrvatskim slavistom Josipom Hammom (1905. - 1986.). ${ }^{3}$ Naime, radi se o ukupno 18 pisama, a osim njih sačuvane su i četiri razglednice te tri brzojava, ${ }^{4}$ čiji sadržaj doprinosi boljem poznavanju njihova života i znanstvenoga rada u razdoblju komunističke Jugoslavije. Njihova korespondencija datira iz razdoblja od 1951. do 1965. godine. U početku njihova dopisivanja Mandić je boravio u Rimu, a krajem 1951. godine odlazi u Chicago gdje ostaje sve do svoje smrti 1973. godine. Hamm je do 1960. godine bio profesor slavenske filologije na Filozofskom fakultetu u Zagrebu, kada odlazi u Beč gdje djeluje također kao profesor slavenske filologije te voditelj Katedre za slavistiku. Posebno treba istaknuti njegovu ulogu (zajedno sa Svetozarom Rittigom i Vjekoslavom Štefanićem) u obnavljanju krčke Staroslavenske akademije 1948., odnosno osnivanju Staroslavenskoga instituta 1952. godine. Njihova su pisma opsegom od jedne do tri stranice a pisana su s obostranim velikim poštovanjem i u prijateljskome tonu. Sva pisma imaju jasne vremenske oznake a izuzetke nalazimo u nekim

1 O Dominiku Mandiću više u: Bazılıje Pandžıć, Životopis dr. fra Dominika Mandića, OFM, ZIRAL, Chicago, 1994.; RoBERT Jolić, Leksikon hercegovačkih franjevaca, Hercegovačka franjevačka provincija Uznesenja BDM - Franjevačka knjižnica Mostar, Mostar, 2011., str. 236-238.

2 Mandićeva ostavština (broji oko 35.000 dokumenata), prema njegovoj oporučnoj želji, čuva se u Arhivu Hercegovačke franjevačke provincije, a povjesničarima je dana na uvid prilikom organiziranja znanstvenoga skupa povodom 50. obljetnice njegove smrti, nakon čega je izišao i zbornik radova. O tome više: Robert Jolić (prir.), Dr. fra Dominik Mandić (1889. - 1973.). Zbornik radova sa znanstvenoga simpozija održanog u prigodi 40. obljetnice njegove $s m r t i$, Hercegovačka franjevačka provincija Uznesenja BDM - Franjevačka knjižnica Mostar - Hrvatski institut za povijest, Mostar - Zagreb, 2014.

3 Osnovni podatci: "Hamm, Josip", u: Hrvatska enciklopedija (dalje: HE), IV., Zagreb, 2002., str. 454-455. Više o njegovu životu i znanstvenom radu u: AloJz JEMBRIH (ur.), Josip Hamm i njegovo djelo. Zbornik radova s međunarodnoga znanstvenoga skupa povodom 100. obljetnice rođenja Josipa Hamma, Zagreb, 2.-3. prosinca 2005., Hrvatski studiji Sveučilišta u Zagrebu, Zagreb, 2007.

4 U navedenoj korespondenciji Mandić je pošiljatelj 10 pisama, a u ostalih 8 pisama te 3 brzojava i 4 razglednice je adresat. 
razglednicama i telegramima. No, po njihovu sadržaju može se približno odrediti i vrijeme njihova nastanka.

Cjelokupna korespondencija Mandić - Hamm donosi, prije svega, podatke o međusobnoj podršci i razmišljanjima ove dvojice znanstvenika o temama koje su bile predmet zajedničkoga znanstvenog interesa, ali iz nje se također može vidjeti i jedan krug uglednih znanstvenika s kojima su obojica komunicirali te neki segmenti iz njihova privatnog života. Podatci iz njihove korespondencije mogu dopuniti dosadašnje spoznaje vezane uza život i rad ove dvojice znanstvenika ali također mogu biti od koristi $\mathrm{u}$ daljnjem proučavanju različitih tema vezanih uz ovo razdoblje hrvatske povijesti.

\section{Sadržaj pisama}

Kako je spomenuto, korespondencija između ova dva znanstvenika trajala je, s kraćim prekidima, od 1951. do 1965. godine. Njihov prvi susret dogodio se najvjerojatnije 1951. godine za vrijeme Hammova boravka u Italiji, pri čemu je važnu ulogu imao Svetozar Rittig. ${ }^{5} \mathrm{Na}$ takav zaključak upućuje brzojav od 3. travnja 1951. kojim Rittig javlja Mandiću da Hamm "putuje u srijedu" i da će mu se javiti u Rimu. ${ }^{6}$

Nakon susreta u Rimu, Josip Hamm upućuje 19. svibnja 1951. (na tri stranice) pismo Mandiću u kojemu se najprije ispričava što se nije ranije javio, pojašnjavajući potanko kako su u pitanju bili zdravstveni problemi u njegovoj obitelji. Sljedeći navodi pisma kazuju kako Hamm planira uskoro ponovni odlazak u Italiju kako bi obavio "ono, za što sada nije bilo vremena", navodeći kako je "prof. Giannelli (je)

5 Osnovni podatci: "Rittig (Ritig), Svetozar", u: HE, IX., Zagreb, 2007., str. 372.

6 O Hammovu boravku u Rimu saznajemo i iz brzojava kojega je 3. travnja 1951. Mandiću uputio Svetozar Rittig, a koji mu javlja da Hamm "putuje u srijedu" i da će mu se javiti u Rimu. Arhiv HercegovačKe FranjevačKe ProvinciJe (dalje: AHFP), Mandićeva ostavština, sv. 4, mapa 3, f. 576.

7 Ciro Giannelli (1905. - 1959.), skriptor Vatikanske knjižnice i profesor na Sveučilištu u Rimu. Gianelli je zajedno s dubrovačkim filologom Milanom Rešetarom priredio dubrovački ćirilski molitvenik iz 1512. godine. Milan REŠETAR - ĆIro ĐANELI (prir.), Dva dubrovačka jezična spomenika iz XVI. vijeka, Srpska kraljevska akademija. Posebna izdanja, knj. CXXII., Filosofski i filološki spisi, knj. 32, Beograd, 1938., str. LX+109 (ćir.). Dubrovački ćirilski molitvenik je prvi ćirilicom tiskan katolički molitvenik koji je sačuvan u tri primjerka (jedan se nalazi u Parizu, drugi u Washingtonu a treći u Oxfordu). Prema primjerku iz Pariza, koji je najpotpuniji, u novije vrijeme tiskana je 
mišljenja, da bi u Napulju moglo biti naših stvari, samo bi trebalo sustavno pregledati njihov trezor". ${ }^{8}$

Hamm piše kako je usprkos navedenim problemima nastojao ispoštovati sve što su se dogovorili. Naime, predao je naliv pero "Monsignoru"9 koji je bio "vrlo tronut, kada sam mu predao Vaš dar". ${ }^{10}$ Osim Svetozara Rittiga, u ovome pismu spominju se i profesori Antun Barac, Stjepan Ivšić, Mirko Deanović i Petar Skok, kojima je Hamm prenio Mandićeve pozdrave. ${ }^{11}$ No, najveći dio ovoga pisma odnosi se na knjige koje je Hamm obećao nabaviti Mandiću. Riječ je o pet svezaka Hrvatske enciklopedije te Rječniku, za koje je, usprkos navedenim problemima, našao vremena i uložio napor da dođe do njih. O problemima oko nabave ovih knjiga Hamm piše:

"Kod Enciklopedije, od koje se s dobrim vezama još i mogu nabaviti četiri prva sveska /nova/, teško je s petim sveskom, koji je doštampan neposredno pred slom, tako da je jedva 100 primjeraka uvezano, a ostalo je kasnije uništeno, pa je spomenuti svezak prava bibliofilska rijetkost, i nema je ni naš Rektorat, ni Dekanat, ni prof. Barac, Ivšić itd. itd. Zato mi je još više bilo stalo, da ga za Vas nabavim, i nabavio sam ga, pa dok Vam pišem ove retke, svih je pet svezaka već na putu k Vama. Nadam se, da ćete biti zadovoljni / premda sam omotnice morao isposuđivati od znanaca, jer ih nije bilo/ i da ćete ih s ponosom moći pokazivati Talijanima, jer kada sva iziđe - naša Enciklopedija ne će ništa zaostati za njihovom.

knjiga: Anica Nazor (ur.), Hrvatski ćirilički molitvenik 1512. (u povodu 500. obljetnice izlaska Molitvenika, Hrvatska akademija znanosti i umjetnosti Nacionalna i sveučilišna knjižnica - Matica hrvatska, Zagreb, 2013. O ovoj knjizi pisali su: StJePAn DAmjanović, "Najstarija hrvatska ćirilicom tiskana knjiga", u: Vijenac, 520, Zagreb, 2014., str. 13-15; Ivan BотісA, "Iz riznice hrvatske ćirilične baštine", u: Slovo, 64, Zagreb, 2014., str. 250-253.

8 AHFP, Mandićeva ostavština, sv. 4, mapa 3, f. 237. Već u sljedećem pismu Hamm će Mandiću iznijeti plan svojih znanstvenih istraživanja u Italiji.

9 Radi se o Svetozaru Rittigu koji se spominje u još nekoliko njihovih pisama.

10 AHFP, Mandićeva ostavština, sv. 4, mapa 3, f. 237.

11 "Jednako Vam mnogo zahvaljuju za pozdrave gg. prof. Barac, Ivšić, Deanovic i Skok, koji Vas svi iskreno i duboko poštuju. S prof. Skokom sam i jučer o Vama razgovarao". AHFP, Mandićeva ostavština, sv. 4, mapa 3, f. 237. Osnovne podatke o ovim uglednim hrvatskim znanstvenicima vidjeti: "Barac, Antun", u: HE, I., Zagreb, 1999., str. 606; "Ivšić, Stjepan", u: HE, V., Zagreb, 2003., str. 230-231; "Deanović, Mirko", u: HE, III., Zagreb, 2001., str. 46; "Skok, Petar", u: HE, IX., Zagreb, 2007., str. 831-832. 
Rječnik sam također nabavio i poslat ću ga za koji dan. Uspio sam dobiti primjerak, koji je bio nabavljen za Predsjedništvo Akademije / odn. kupila ga je Znanstvena knjižnica Akademije; Predsjedništvo nije imalo nijednog primjerka vezana u kožu, a meni su ga dali samo zato, što i sam surađujem u Rječniku, odn. radim na njegovu nastavljanju. Prof. Novak, koji je također pokrenuo sve i sva da dobije jedan komplet, nije ga dobio, isto tako ni prof. Deanović/. Odjel za jezik i književnost priredio je za štampu cijelu XII i XIII knjigu i nada se, da će doskora dovršiti i preostale četiri, tako da će to veliko djelo naše leksikografije u dogledno vrijeme biti potpuno. / A propos, u ovih 11 knjiga, koje Vam šaljem, sadržano je 50 svezaka; 51. i 52. svezak već su izašli, a cijela XII knjiga imala bi izaći u idućoj godini. Meni je Akademija, odn. Znanstvena knjižara Akademije obećala, da će i ostale knjige za me / odn. za Vas/ dati uvezati isto onako kako je uvezano i tih 11/."12

Vezano uza spomenute knjige Hamm naglašava kako mu je teško "odvajati se od ovih knjiga: ni ja naime nemam pete knjige Enciklopedije, a i moj Rječnik je i danas neuvezan i dijelom iskidan. Zato, razumjet ćete, da ih ovdje ne bih dao nikomu", a njemu ih šalje jer zna "da će doći u ruke čovjeku, koji će ih znati cijeniti onako, kako one to zaslužuju". ${ }^{13}$

Da je Mandić naručio još neke knjige vidi se iz sljedećega navoda u pismu: "Što se tiče djela, koja predstavljaju obvezu Staroslavenske akademije prema Vama, mogu Vam javiti, da će se i tu doskora početi sa slanjem / iz Ljubljane su već dobili popis djela, koja se mogu nabaviti; to isto zatraženo je i iz Beograda, a Monsignor je sam na sebe uzeo da govori s glavnim tajnikom prof. Kostrenčićem, da bi se za tu svrhu dobila i što potpunija izdanja naše Akademije/."14

Nakon toga, Hamm napominje kako će se potruditi nabaviti mu, ako ikako bude mogao, i druge knjige koje mu budu potrebne. ${ }^{15} \mathrm{Na}$ kraju Hamm piše kako Mandiću uime svoje supruge "kojoj sam nejednom govorio o našim motivima u Vašoj crkvi i zgradi Generalizie," šalje "album s snimkama nekih naših krajeva, tek toliko, kao sitni darak iz

12 AHFP, Mandićeva ostavština, sv. 4, mapa 3, f. 237-238.

13 AHFP, Mandićeva ostavština, sv. 4, mapa 3, f. 238.

14 AHFP, Mandićeva ostavština, sv. 4, mapa 3, f. 238.

15 AHFP, Mandićeva ostavština, sv. 4, mapa 3, f. 238. 
Domovine", te pozdravlja njega i ostale franjevce u Rimu i zahvaljuje na svemu. ${ }^{16}$

Iste godine 11. srpnja Hamm ponovo piše Mandiću. U ovome pismu najprije govori o knjigama koje su prema dogovoru on i S. Rittig trebali poslati D. Mandiću. Ovdje saznajemo da je Hamm poslao Mandiću "i Enciklopediju i Rječnik", a da će uskoro biti tiskan "Katalog izdanja naše Akademije znanosti, pa će tada i Monsignor, koji Vam je, kako čujem, već poslao popise ljubljanskih i beogradskih izdanja, moći započeti sa slanjem knjiga, kojima će se namiriti materijalna strana izdataka za moj put u travnju, i stvoriti kakva takva podloga za kasnije naše potrebe". ${ }^{17}$

U ovome pismu Hamm također Mandića upoznaje s radom na Staroslavenskoj akademiji ${ }^{18}$ navodeći kako uza sve poteškoće čine "nešto, što će ipak ostati trajno". Tekst glasi:

"Mi smo upravo ovih dana završili ekscerpiranje glag. misala /Ed. Pr./ i sada pristupamo obrađivanju, iza kojega će slijediti štampanje rječnika, prvoga te vrste u našem glagolizmu, koji će jednako služiti i Crkvi i nauci, a bit će tako sastavljen, da će dobro poslužiti kod redakcije Mrtvačkog misala i dopunskih misa, koje nedostaju Vajsovu misalu iz god. 1927.

Na glagoljaškom skupu, koji je ovih dana održan u Pazinu u Istri, bilo je govora o tome, da se u dogledno vrijeme pristupi redigiranju brevijara hrvatske recenzije za potrebe naših glagoljaša, jer je zaista nezgodno, da se oni i danas od nevolje služe brevijarima iz god. 1791, koji su sasvim u znaku ruske recenzije. Doduše, s jedne strane se govorilo, kao da Sv. Stolica - navodno - ne bi bila nesklona da u našim specifičnim prilikama dopusti i uvođenje književnoga jezika / današnjega/ što bi, naravno, glagolanje jednim zamahom učinilo anahronizmom - ali ja sve nekako u to sumnjam, i ne mislim, da bi do toga moglo skoro doći. Zato smo u Starosl. akademiji odlučili ipak - bez obzir na bilo što - ovih dana započeti s ekscerpiranjem glag. brevijara, da bismo tako dobili historijski rječnik, u kojem će u glavnim obrisima

16 AHFP, Mandićeva ostavština, sv. 4, mapa 3, f. 238-239.

17 AHFP, Mandićeva ostavština, sv. 4, mapa 3, f. 295.

$18 \mathrm{Na}$ čelo Staroslavenske akademije 1948. godine imenovan je Svetozar Rittig, na čiji je prijedlog Akademija 1952. godine postala Staroslavenski institut, a od iste godine počinje izlaziti časopis Slovo i Radovi Staroslavenskog instituta. "Staroslavenski institut", u: HE, X., Zagreb, 2008., str. 225. 
biti okupljeno naše leksičko blago od prvih početaka naše pisane riječi do Marulića. Tako će, ako glagoljašima i ne bude potreban novi brevijar, bar naša nauka, a po njoj i naša kulturna povijest dobiti nešto, što nam je u historijskim naukama vrlo nedostajalo. $U$ tu svrhu ekscerpirat će se i isporediti - prema sadašnjem planu - građa iz 9 brevijara / od kraja XIII do kraja XV vijeka, među njima i onaj, koji se kao Illirico 5 nalazi u Vaticanu. Tamo do godine bit će nam jamačno potrebne fotografije toga kodeksa / zasada imamo 5 fotografiranih kodeksa, koji za taj posao dolaze u obzir, već ovdje u Zagrebu.

Tako, kako vidite, ipak i pored svih teškoća, pokušavamo nešto učiniti, nešto, što će ipak ostati trajno."19

U daljnjem tekstu Hamm pojašnjava Mandiću svoje planove oko godišnjega odmora i svoga znanstvenoga istraživanja. Naime, iz pisma saznajemo kako je planirao tri tjedna odmora provesti s obitelji u Lošinju gdje će "nastojati spojiti utile cum dulci: pregledati tamošnja glagolitica / kojih je uza svu italianizaciju ostalo desetak različnih rukopisa/ i prokontrolirati tamošnji dijalekat, koji je već ranije bio obrađivan". ${ }^{20}$ Nakon toga Hamm je planirao ići u Italiju, iskazujući žaljenje u pismu što nije uspio ranije "temeljito pregledati njihovu zbirku rukopisa, među kojima, kako me i drugi uvjeravaju, ima i naših stvari. Zato bih na svaki način htio to popraviti ..." Hamm je planirao i u Firenzi napraviti popis književne baštine prof. Rešetara, pa stoga moli Mandića da mu pomogne realizirati to putovanje. Napominje kako bi Mandiću osim već poslanih knjiga poslao i druge koje bude poželio. Hammov je plan bio krajem kolovoza ili početkom rujna doći u Italiju zajedno sa suprugom, koja bi mu, kako navodi, mnogo pomogla pa bi se mogao "mirnije posvetiti svojem radu". Hamm napominje kako svoju molbu upućuje "bez znanja Monsignora Ritiga", kojega također planira moliti za pomoć oko dobivanja putovnice za svoju suprugu i vize za njega. U istom pismu Hamm navodi kako je na glagoljaškom skupu u Pazinu od S. Rittiga čuo kako Mandić planira u kolovozu odlazak u SAD. ${ }^{21}$

Na navedeno pismo Mandić odgovara 9. kolovoza 1951. iz Montecatini Terme gdje je planirao ostati još pet dana. ${ }^{22} \mathrm{Na}$ početku navodi kako zbog priprema za put u SAD nije mogao ranije odgovoriti na

19 AHFP, Mandićeva ostavština, sv. 4, mapa 3, f. 296.

20 AHFP, Mandićeva ostavština, sv. 4, mapa 3, f. 296.

21 AHFP, Mandićeva ostavština, sv. 4, mapa 3, f. 296.

22 AHFP, Mandićeva ostavština, sv. 4, mapa 3, f. 346. 
Hammovo posljednje pismo, te je čekao da stigne "Vasa pošiljka Akademskoga rjecnika" kojeg je kao i Hrvatsku enciklopediju pohranio u knjižnicu za Hercegovačku franjevačku provinciju, u koju planira ostaviti i ostale knjige koje mu Hamm bude poslao. Mandić nadalje piše: "Na racun tih knjiga voljan sam Vam iz fonda hercegovacke provincije omoguciti zeljeni boravak u Italiji, Vama i Vasoj gdi supruzi. Bit će mi drago da Vam na ovaj nacin pomognem u Vasem znanstvenom radu i nastojanju. Dakle, racunajte na me i slobodno dogjite u Italiju". ${ }^{23}$ Iz pisma također saznajemo da je od Rittiga dobio "popise knjiga Slovenske i Srpske akademije" te da čeka "novi cijenik Hrvatske akademije" kako bi mogao naručiti sve ono što smatra potrebnim i korisnim. U pismu također navodi kako još nije dobio vizu za SAD te će ga Hamm, po svemu sudeći, susresti kada dođe u Italiju. ${ }^{24}$

Hamm se ponovo javlja Mandiću pismom od 13. rujna iste godine (nakon što mu je poslao telegram), ispričavajući se što piše rukom. ${ }^{25} \mathrm{U}$ pismu pojašnjava probleme $s$ dobivanjem vize, te se žali kako je ispite stalno odgađao misleći kako će dobiti vizu, te ih mora održati sljedeći tjedan kako bi mogao mirno ići na put. No, "više od ispita" kako navodi, brine ga Mandićev odlazak u SAD jer bi mu bilo žao ako se ne susretnu u Rimu. Napominje kako će Mandiću ponijeti "nekoliko vrijednih izdanja" te da mu javi ukoliko želi da mu još nešto ponese. U pismu ga obavještava i o zdravlju S. Rittiga, navodeći kako je bio u Rogaškoj Slatini i da se sada dobro osjeća, te mu šalje "odulje pismo i poruke", ponavljajući kako se nada da će u Rimu imati priliku izraziti mu "Monsignorovo" i njegovo "odano poštovanje" te pozdrave "koje Vam najugledniji predstavnici našeg kulturnog života šalju". ${ }^{26}$

U sljedećem pismu (20. rujna 1951.) Hamm obavještava Mandića da su gotove vize "tako da sada, zahvaljujući Vašoj dobroti, nema nikakve zapreke da krenemo na put" navodeći kako je upravo primio ovu

23 AHFP, Mandićeva ostavština, sv. 4, mapa 3, f. 346.

$24 \mathrm{Na}$ samom kraju uručuje i "pozdrav i postovanje Preuz. gosp; Ritigu i Vasoj gdi supruzi". AHFP, Mandićeva ostavština, sv. 4, mapa 3, f. 346.

25 "PS. Oprostite što pišem rukom, ali želio bih Vam ove retke poslati neposredno iza brzojava, koji sam uputio danas". AHFP, Mandićeva ostavština, sv. 4, mapa 3, f. 379. U Mandićevoj ostavštini sačuvan je i brzojav s istim nadnevkom (13. rujna 1951.), u kojemu stoji: "radi talijanske vize prisiljeni odgoditi polazak do prvoga". AHFP, Mandićeva ostavština, sv. 4, mapa 3, f. 380. Također, Hamm je još 4. rujna 1951. uputio brzojav Mandiću kojim mu javlja da čekaju vize i da će javiti polazak. AHFP, Mandićeva ostavština, sv. 4, mapa 3, f. 575.

26 AHFP, Mandićeva ostavština, sv. 4, mapa 3, f. 378-379. 
vijest i da će o tome obavijestiti suprugu koja se nalazi kod njegovih roditelja, a onda i "Monsignora koji se s nekim arheolozima nalazi na putu u Posavini odakle se vraća sredinom sljedećega tjedna". ${ }^{27} \mathrm{Nada}-$ lje navodi kako nakon održavanja ispita, najkasnije prvoga u mjese$\mathrm{cu}$, planira krenuti u Monfalcone a onda sljedeći dan biti u Rimu. I u ovome pismu Hamm napominje Mandiću da mu javi ako mu treba što ponijeti, osim izdanja koja je već pripremio. ${ }^{28} \mathrm{U}$ pismu također iznosi plan boravka u Italiji:

"Naš je plan, da se - uz boravak od par dana u Vječnom Gradu - zadržimo 5-6 dana u Napulju, gdje bih imao dosta posla u Nacionalnoj biblioteci, zatim u Firenci /ugl. u vezi sa znan. ostavštinom pok. prof. Rešetara/ i na kraju oko dva dana u Veneziji, gdje bih imao posla u Marciani/ u vezi s glagolitikama i s Matijom Divkovićem/. Naravno, to su samo želje, a mi ćemo Vam oboje biti zahvalni za svaki sat, što ćemo ga - u radu i u upoznavanju - moći provesti u zemlji u kojoj nas Vi bolje i sa više ugleda zastupate nego bilo tko drugi. Mislili smo, da ćemo na Malu Gospojinu biti u Rimu, i toliko nam je bilo žao, što se to tako zavuklo!"29

Pismo završava riječima: "Da ne duljim, očekujući Vaše pismo i Vaše želje i očekujući trenutak, kada ćemo Vas moći pozdraviti, šaljem u ime svoje supruge i u ime svoje naše najtoplije, najsrdačnije pozdrave. Vama uvijek odani Josip Hamm". ${ }^{30}$

O njihovoj daljnjoj komunikaciji u Mandićevoj ostavštini nema podataka do 1957. godine (23. kolovoza) kada Mandić iz Chicaga piše Hammu. U pismu (na dvije stranice) koje potpisuje kao Nedjeljko Mandić, fra Dominik govori kako je prije šest tjedana na Staroslavenski institut u Zagrebu poslao svoja djela: "1) Hrvatski sabor na Duvanjskom polju god. 753. i 2) Crvena Hrvatska u svijetlu povijesnih izvora", ${ }^{31}$ i to s nakanom da se naprave recenzije tih djela za njihov ča-

27 AHFP, Mandićeva ostavština, sv. 4, mapa 3, f. 393.

28 AHFP, Mandićeva ostavština, sv. 4, mapa 3, f. 393.

29 AHFP, Mandićeva ostavština, sv. 4, mapa 3, f. 393-394.

30 AHFP, Mandićeva ostavština, sv. 4, mapa 3, f. 394. Nekoliko dana kasnije Hamm će uputiti brzojav Mandiću (28. rujna 1951.) sa sljedećim sadržajem: "vize stigle radi prijelaza molimo brzojavno obavijest da novac čeka u Monfaconu". AHFP, Mandićeva ostavština, sv. 4, mapa 3, f. 402.

31 Riječ je o njegovim djelima: "Hrvatski sabor na Duvanjskom polju god. 753", u: Hrvatska revija, 7, Buenos Aires, 1957., str. 5-40; Crvena Hrvatska u svijetlu povijesnih izvora, Hrvatski povijesni institut, Chicago, 1957. 
sopis Slovo. Mandić navodi kako Hammu i Rittigu šalje iste rasprave i kako im je prošle godine obojici poslao njegovu raspravu "Postanak Vlaha", ${ }^{32}$ te moli Hamma da mu javi jesu li dobili sve ove knjige. ${ }^{33}$

Nadalje, u pismu Mandić iznosi svoje mišljenje o čakavštini:

"Mislim da će Vas posebno zanimati moji zaključci o čakavštini, govoru kojega su Hrvati donijeli sa zapadnoga slavenskoga područja (Crvena Hrvatska 187-203) te o 'Methodos'u, upravnom djelu napisanu na osnovu zaključaka hrvatskoga sabora na Duv. polju god. 753. (Hrv. sabor 34-38). Do tih zaključaka ja sam došao proučavajući najstariju povijest Hrvata i raširenost čakavštine po svim krajevima, gdje su negda prebivali Hrvati. Ja bih imao o tim pitanjima još šta reći, ali sam morao biti kratak radi ograničenoga prostora, s kojim sam raspolagao. Želim, da Vi ili tko drugi u 'Slovu' prikažete i podvrgnete kritici moje zaključke i da ta pitanja još dublje stručnjački produbite. Ja nijesam jezikoslovac nego historički kritičar, pa ako bude stvarnih povjesnih prigovora, ja sam voljan za moje zaključke iznijeti nove dokaze u Vašem časopisu ili u kojemu drugomu povjesnom zborniku u Zagrebu." 34

U istome pismu Mandić daje neke prijedloge oko proučavanja čakavštine: "Bilo bi korisno i potrebno, da koji hrvatski jezikoslovac temeljito ispita odnošaj stare i današnje čakavštine za slavenskim zapadnim jezicima, posebno sa starim govorom istočnih Čeha, Moravaca, Slovaka i Poljaka oko Krakova. Kod toga bi trebalo uzeti u obzir i najstarije mjesne nazive u zapadnoj Hrvatskoj i Karantanskoj Hrvatskoj, koji odaju karakteristike slavenskih zapadnih jezika. A i staroslavenski $\underline{\text { }}$ prešlo je u čakavštini u a jednako kao i u češkom jeziku.

Nadalje bih Vas molio, da Vi s Vašim suradnicima i učenicima organizirate proučavanje ostataka čakavštine po svim hrvatskim zemljama: u makarskoj krajini, u B. i H., u Slavoniji, na području bivše dubrovačke republike, u Boki Kotorskoj i u Crnoj Gori. Ako se to ne učini u dogledno vrijeme, mnoge čakavske odlike iščeznut će uslijed povećane naobrazbe i megjusobnoga općenja naroda iz jednoga kraja s drugim. Kod proučavanja trebalo bi osobito pripaziti na izraze i go-

32 Dominik Mandić, "Postanak Vlaha prema novim poviestnim istraživanjima", u: Hrvatska misao, sv. 18-19, Buenos Aires, 1956., str. 1-48.

33 AHFP, Mandićeva ostavština, sv. 6, mapa 4, f. 129r.

34 AHFP, Mandićeva ostavština, sv. 6, mapa 4, f. 129r. 
vor starijih osoba, muških i ženskih, osobito onih, koji su nepismeni i nijesu mnogo hodali po drugim krajevima naše domovine". ${ }^{35}$

Nakon toga, Mandić piše kako u franjevačkoj biblioteci imaju izdanja Staroslavenskoga instituta: "Slovo I-V te Radove I-II." te moli Hamma da mu pošalje kasnija izdanja, ukoliko ih ima, a da će on njemu poslati svoje daljnje radove i izdanja Hrvatskoga povijesnog instituta. Nakon toga piše kako trenutačno radi na raspravama: "1) Kako su govorili stari Hrvati i Srbi?; 2) Hrvatska pisana djela sedmoga do dvanaestoga vijeka" koja će, prema njegovu mišljenju izići na engleskome jeziku. ${ }^{36}$

Na raniju Mandićevu zamolbu da se naprave recenzije njegovih djela: "1) Hrvatski sabor na Duvanjskom polju god. 753. i 2) Crvena Hrvatska u svijetlu povijesnih izvora", ${ }^{37}$ te se objave u časopisu Slovo Hamm odgovara na jednoj čestitci (nema datacije), ${ }^{38}$ na kojoj pod post scriptum piše kako je primio ove dvije Mandićeve knjige ali da još nije našao recenzente, jer želi "objektivne recenzije, koje bi pravedno ocijenile golemi trud, koji ste u njih uložili. Istina se često teško probije kroz vela i osude, ako one nisu baš željene". ${ }^{39}$

Sljedeće sačuvano pismo datira iz 1961. godine. Naime, te godine (23. veljače 1961.) Mandić piše Hammu na Staroslavenski institut u Zagrebu kako mu je prije nekoliko tjedana poslao prvi svezak djela "Bosna i Hercegovina" ${ }^{\prime \prime 0}$ navodeći "To je djelo strogo znanstveno i ja se nadam, da se i kod vas cijeni slobodno istraživanje i mirna znanost, pa

35 AHFP, Mandićeva ostavština, sv. 6, mapa 4, f. 129r.

36 AHFP, Mandićeva ostavština, sv. 6, mapa 4, f. 129r. Na kraju pisma pozdravlja monsignora Rittiga i sve djelatnike Staroslavenskoga instituta, a "Ako vidite oca D.B. izručite mu pozdrav". AHFP, Mandićeva ostavština, sv. 6, mapa 4, f. 130v.

37 AHFP, Mandićeva ostavština, sv. 6, mapa 4, f. 129r.

38 "Iznenada evo i mene! Svako dobro i mnogo sreće i uspjeha želi Vam u god. 1958. također Vaš odani Josip Hamm". AHFP, Mandićeva ostavština, sv. 6 , mapa 5, f. 02.

39 AHFP, Mandićeva ostavština, sv. 6, mapa 5, f. 02.

40 Riječ je o prvom svesku Mandićeva djela Bosna i Hercegovina. Povjesno-kritička istraživanja, a naslov sveska glasi: Državna i vjerska pripadnost sredovječne Bosne i Hercegovine, Hrvatski povijesni institut, Chicago, 1960. Knjiga je doživjela još dva izdanja: Državna $i$ vjerska pripadnost sredovječne Bosne $i$ Hercegovine, ZIRAL, Chicago - Rim, ${ }^{2}$ 1978.; Miroslav AkmadžA (prir.), Dominik Mandić. Sabrana djela, sv. II., Hercegovačka franjevačka provincija Uznesenja BDM - Franjevačka knjižnica - FRAM ZIRAL, Mostar, ${ }^{3} 2013$., str. 39-379. 
da ne će biti zapreka za primanje i čitanje tog djela".41 Nadalje navodi kako dovršava drugi svezak djela "Bosna i Hercegovina" s naslovom "Bogomilska crkva bosanskih krstjana",42 te kako bi knjiga trebala izići iz tiska sredinom 1961. godine. O toj knjizi Mandić piše: "Temeljito sam proučio domaće i strane izvore i došao sam do novih utvrgjenja, koji će služiti na unaprijegjenje boljega poznavanja novomanihejskoga pitanja kod nas i u sredovječnoj Evropi uopće". ${ }^{43} \mathrm{Na}$ kraju govori kako sa zanimanjem prati izdanja Staroslavenskoga instituta, te kako u franjevačkoj knjižnici imaju "Slovo sv. 1-8, te Radove sv. I i II.", pa moli Hamma da mu pošalje sve ono što su naknadno izdali a on će njemu poslati neka svoja djela na hrvatskome i engleskome jeziku, kada mu Hamm potvrdi da je dobio navedenu knjigu. ${ }^{44}$

Sljedeće godine (12. svibnja 1962.) Mandić piše Hammu kako je čitajući Slovo saznao da se i Hamm interesira za "bogomilsko pitanje u Bosni", pa mu je iz toga razloga poslao svoju knjigu "Bogomilska crkva bosanskih krstjana", ${ }^{45}$ te napominje da bi mu bilo drago "da o tome progovorite u jednom broju Slova". Nadalje se interesira o djelu koje govori o sv. Ćirilu i Metodu. Mandić piše: "Na omotnoj strani istoga Slova čitam, da msgr Grivec i Tomšić spremaju novo izdanje života sv. Ćirila i Metoda. ${ }^{46}$ Ako je to djelo već izišlo budite dobar, pa mi odmah opremite jedan primjerak uvezan, ako imate; ako djelo još nije izišlo, javite mi, kada se može očekivati objelodanjenje istoga". Na kraju ponovno spominje kako franjevačka biblioteka ima časopise "Slovo I-X, i Radove I-III.", te ga moli da ih uvrste u redovite

41 AHFP, Mandićeva ostavština, sv. 7, mapa 3, f. 31.

42 Riječ je o drugome svesku Mandićeve trilogije s naslovom: Bosna i Hercegovina. Povjesno-kritička istraživanja, a naslov je: Bogomilska crkva bosanskih krstjana, Chicago, 1962. Kasnije su izišla još dva izdanja ove knjige: Bogomilska crkva bosanskih krstjana, ZIRAL - Zajednica izdanja ranjeni labud, Chicago - Roma - Zürich - Toronto, 1979.; Miroslav AkmadžA (prir.), Dominik Mandić. Sabrana djela, sv. III., Hercegovačka franjevačka provincija Uznesenja BDM - Franjevačka knjižnica - FRAM ZIRAL, Mostar, ${ }^{3} 2013$., str. 9-410.

43 AHFP, Mandićeva ostavština, sv. 7, mapa 3, f. 31.

44 AHFP, Mandićeva ostavština, sv. 7, mapa 3, f. 31.

45 Dok je radio na ovoj knjizi, ali i nakon njezina tiskanja, Mandić je na temu Crkve bosanske komunicirao s mnogim uglednim znanstvenicima, o čemu brojne podatke nalazimo u njegovoj rukopisnoj ostavštini. AHFP, Mandićeva ostavština, sv. 6, 7, 13, passim.

46 Riječ je o djelu: Franciscus Grivec - Franciscus Tomšić, "Constantinus et Methodius Thessalonicenses: Fontes", u: Radovi Staroslavenskog instituta, 4, Zagreb, 1960., str. 13-276. 
pretplatnike i pošalju sve brojeve koji su nakon toga izišli šaljući mu adresu u Chicagu. ${ }^{47}$

Iz sljedećega pisma saznajemo da je Josip Hamm 1962. godine boravio u New Yorku. Naime, 5. rujna 1962. Mandić mu piše pismo na adresu u navedenome gradu, navodeći kako mu nije moguće doći u New York ali bi se htio s njim čuti i telefonski razgovarati, te mu šalje svoj telefonski broj i predlaže termine za obavljanje telefonskih razgovora. Sljedeći redci njegova pisma ukazuju na to da se Hamm nije javio na njegovo ranije pismo (23. veljače 1961.) jer Mandića i u ovome pismu zanima je li izišao ijedan broj časopisa Slovo i Radovi nakon 1960. godine, te ga moli, ukoliko jest, da mu te brojeve pošalje. Navodi kako mu je krajem travnja 1962. na Staroslavenski institut poslao knjigu Bogomilska crkva bosanskih krstjana te se zanima je li je primio i bi li mogao napisati prikaz ove knjige za časopis Slovo. Navodi i kako mu se javio A. V. Solovjev ${ }^{48}$ s konstatacijom da je knjiga "iscrpna i temeljita" te da će objaviti recenziju knjige u časopisu "'Byzantion'-u Parizu - Bruxellesu" a da će prof. Ivan Dujčev ${ }^{49}$ objaviti prikaz knjige u "Byzantino-slavica u Pragu". ${ }^{50}$

Nadalje Mandić piše kako je u svojim istraživanjima došao do zaključka "da su Hrvati došli na jug u drugoj seobi Slavena i da su tada govorili čakavski, i to govorom ikavskim i ijekavskim". Stoga, predlaže Hammu da sugerira nekom doktorandu da u svojoj doktorskoj disertaciji istraži "čakavsko narječje u južnoj Poljskoj i zapadnoj Rusiji", navodeći kako mu je pričao Vjekoslav Mandić "sadašnji predsjednik Hrv. Bratske Zajednice u Pittsburghu, čakavac iz Istre" da je za vrijeme Prvoga svjetskog rata susreo "prave čakavce južno od Premisla i sjeverno od Karpata". Također mu sugerira i da bi bilo potrebno

47 AHFP, Mandićeva ostavština, sv. 7, mapa 4, f. 26.

48 O Aleksandru V. Solovjevu (1890. - 1971.) više u: Sima Avramović, "Solovjev (Solovëv) Aleksandar Vasilijevič", u: Sima Ćır Ković - Rade Minaljčıć (prir.), Enciklopedija srpske istoriografije, Beograd, 1997., str. 640-642 (ćir.).

49 Ivanu Dujčevu (1907. - 1986.) posvećena su dva sveska radova u Godišnjaku sofijskoga Sveučilišta odnosno Centra koji nosi ime ovoga znanstvenika. O tome: Marija-Ana DürRIgL, "Godišnik na Sofijskija universitet 'Sv. Kliment Ohridski', Cent'r za slavjano-vizantijski proučvanija 'Ivan Dujčev' = Annuaire de l' Universite de Sofia 'St. Kliment Ohridski' Centre de recherches slavobyzantines 'Ivan Dujčev"', tom 89 (8), (za 1997. g.), Sofija, 2001., str. 5-189 + ilustracije", u: Slovo, 54-55, Zagreb, 2004. - 2005., str. 253-257.

50 AHFP, Mandićeva ostavština, sv. 7, mapa 4, f. 227. O tome više u: Dijana KoRAĆ, "Crkva bosanska u korespondenciji između Dominika Mandića i Aleksandra V. Solovjeva", u: Croatica christiana periodica, 82, Zagreb, 2018., str. 37-39. 
da Hamm preko svojih suradnika iz Staroslavenskoga instituta ispita "čakavske ostatke u Bosni do Drine i u Hercegovini i Crnoj Gori". ${ }^{51}$ Pod p. s. piše kako bi krajem 1962. godine u Rimu trebao izići zbornik njegovih rasprava iz stare hrvatske povijesti koje je pisao posljednjih deset godina. ${ }^{52}$

$\mathrm{Na}$ ovo pismo Hamm odgovara dva dana kasnije (7. rujna 1962.) u vrijeme kada je odlazio iz New Yorka. Hamm najprije izražava žaljenje što je kasno dobio pismo i što se nisu uspjeli vidjeti, a da ga vjerojatno ne bi zatekao doma, ukoliko bi ga sada nazvao. Nadalje kaže kako Mandićevu knjigu Bogomilska crkva bosanskih krstjana nisu dobili na Staroslavenskome institutu, a ukoliko je u međuvremenu budu dobili, rado će napisati prikaz knjige napominjući "jer me - kao što znate - i sva pitanja u vezi s bogumilima vrlo interesiraju". ${ }^{53}$

U pismu se opširnije osvrće na Mandićeve prijedloge o čakavštini:

"Vaše su sugestije u vezi s čakavštinom vrlo zanimljive. I ja sam u svojim studijama došao do zaključka u prvom redu čakavci - u užim vezama sa zapadnim Slavenima nego sa štokavskim susjedima koji su naselili istočni dio Balkanskog poluotoka. O tome sam dao u štampu članak koji će za koji mjesec izaći u 'Wiener slavist. Jahrbuch', pa ću Vam ga poslati. Samo teško će biti sa čakavcima u južnoj Poljskoj i istočnoj Rusiji, o kojima inače ništa nije pobliže poznato. Ja ću se zasada posvetiti proučavanju naših čakavskih i kajkavskih govora u Gradišću u Austriji". ${ }^{4}$

Na kraju pisma izražava žaljenje što se ne će čuti ni vidjeti pa mu ne će moći reći "koliko Vas poštuju i koliko Vas se rado sjećaju u staroj domaji", te zahvaljuje "na daru, koji će mnoge obradovati!"55

Sljedeće sačuvano pismo datira iz 1964. godine. Naime, 10. rujna Mandić piše Hammu kako je čuo da je Hamm otišao na "Bečku univerzu"56 navodeći: "Iako je to veliki gubitak za našu univerzu

51 AHFP, Mandićeva ostavština, sv. 7, mapa 4, f. 227r-227v.

52 AHFP, Mandićeva ostavština, sv. 7, mapa 4, f. 227v.

53 AHFP, Mandićeva ostavština, sv. 7, mapa 4, f. 228.

54 AHFP, Mandićeva ostavština, sv. 7, mapa 4, f. 228.

55 AHFP, Mandićeva ostavština, sv. 7, mapa 4, f. 228v.

56 J. Hamm je radio na Sveučilištu u Beču od 1960. do 1976. godine (bio je redoviti profesor slavenske filologije te voditelj Katedre za slavistiku). Također bio je i upravitelj Instituta za slavistiku (Institut für Slawistik der Universität 
u Zagrebu, ipak mi je drago, da ste došli u slobodnu zemlju, gdje ćete moći znanstveno raditi bez pritiska ideologija i nasilne vlasti". Nadalje napominje kako mu je prije godinu dana poslao knjigu Bogomilska crkva bosanskih krstjana i da nije dobio potvrdu od njega da ju je primio pa ukoliko nije, poslat će mu je opet jer zna da ga to pitanje zanima, te da je u knjizi citirao i Hammov rad "Apokalipsa bosanskih krstjana". ${ }^{57}$ Mandić također navodi kako mu je nedavno poslao i djelo Rasprave i prilozi iz stare hrvatske povijesti ${ }^{58}$ u kojemu će biti puno stvari koje zanimaju Hamma. Posebno mu ukazuje na podatak u knjizi gdje se navodi kako su 1911. godine "neki iz okolice Krakova useljavali u USA pod imenom: 'Bielochrovats (Cracovinians)'", te zaključuje kako se do sada mislilo da je "hrvatsko ime iščezlo na sjevero (sic!) još u 11. stoljeću, a eto iz navedenoga djela saznajemo, da su Bijeli Hrvati u Maloj Poljskoj sačuvali svoje ime, barem u nekim krajevima oko Krakova, sve do početka 20. stoljeća". Nakon ovoga Mandić predlaže Hammu da nekome svome učeniku sugerira da "istraži uporabu imena Hrvat u Južnoj Poljskoj od Porfirogeneta do naših dana. To bi mogli savjetovati i kojemu Vašem poznaniku u Poljskoj". ${ }^{59} \mathrm{Na}$ kraju Mandić piše kako 2. prosinca navršava 75. godina života i da tom prigodom Hrvatski povijesni institut u Rimu planira izdati zbornik radova, pa ga moli da za taj zbornik napiše neki prilog iz "bogomilske problematike" ito do sredine studenoga. ${ }^{60}$

Samo pet dana kasnije (15. rujna 1964.) Hamm se javlja Mandiću iz Ann Arbora. Naravno, ne odgovara na njegovo ranije pismo jer ga do tada nije mogao ni dobiti. Hamm piše Mandiću kako će se vjerojatno začuditi što se javlja iz Ann Arbora i da je došao na poziv njihova sveučilišta te da će ostati do Božića kada odlazi najprije za Zagreb a potom za Beč. Nadalje, Hamm piše kako bi volio vidjeti Mandića, te predlaže, znajući da u Chicagu ima mnogo Hrvata, da održi neko pre-

Wien). O tome više u: Alojz Jembrin, "Bečka slavistika prije i za Hammova doba", u: Alojz Jembrin (ur.), Josip Hamm i njegovo djelo. Zbornik radova s međunarodnoga znanstvenoga skupa povodom 100. obljetnice rođenja Josipa Hamma, Zagreb, 2.-3. prosinca 2005., Hrvatski studiji Sveučilišta u Zagrebu, Zagreb, 2007., str. 197-224.

57 Riječ je o članku: Josıp Hамм, "Apokalipsa bosanskih krstjana", u: Slovo, 9-10, Zagreb, 1960., str. 43-104.

58 Riječ je o djelu: Dominik Mandić, Rasprave i prilozi iz stare hrvatske povijesti, Hrvatski povijesni institut, Rim, 1963.

59 AHFP, Mandićeva ostavština, sv. 13, mapa 1, pm. V, f. 10.

60 AHFP, Mandićeva ostavština, sv. 13, mapa 1, pm. V, f. 10. 
davanje, ako Mandić smatra da bi bilo zainteresiranih, a navodi kako bi za temu najradije uzeo Džoru Držića i govorio "o novom dosada jedinom potpunom rukopisu njegovih pjesama. U njemu je i prvi hrvatski i prvi slavenski - prijevod (i prva versifikacija) 'Ave Maria' i 'Salve Regina"'. Ako se i ne mogne organizirati to predavanje, Hamm napominje da bi mu svakako bilo drago da mu se Mandić javi. ${ }^{61}$

Tri dana kasnije (18. rujna 1964.) Mandić piše Hammu pismo na adresu u Ann Arboru. U njemu najprije iskazuje radost što se Hamm nalazi u SAD-u te nadu da će se uspjeti vidjeti i razgovarati. Nakon toga piše kako mu je prije tjedan dana u Beč poslao raspravu "Rasprave i prilozi iz stare hrvatske povijesti", te ga je ponovo poslao u Ann Arbor. Napominje kako je primjerak poslan u Beč s posvetom a ako ga ne bude dobio da uzme ovaj, koji bi u slučaju da dobije u Beču trebao dati nekoj znanstvenoj knjižnici u Hrvatskoj. ${ }^{62}$

$\mathrm{Na}$ Hammov upit o mogućnosti održavanja predavanja Hrvatima u Chicagu Mandić odgovara kako ne bi bilo interesa za znanstveno predavanje jer "to je odreda radnički svijet, koji nema mnogo smisla za naučna predavanja". Stoga mu predlaže da napiše tekst na predloženu temu i pošalje da se objavi u Hrvatskome kalendaru koji tiskaju hrvatski franjevci u SAD-u za iseljene Hrvate. Napominje kako se sprema Hrvatski kalendar za tisak pa, ukoliko ga namjerava ovdje objaviti da mu javi što prije, a da tekst pošalje bez znanstvenih bilježaka do kraja rujna tekuće godine. ${ }^{63}$

Nakon toga Mandić ponovo spominje kako 2. prosinca navršava 75. godina života i da tom prigodom Hrvatski povijesni institut u Rimu planira izdati zbornik radova, pa ga moli da za taj zbornik napiše neki prilog "iz bogomilske problematike i njihovih Novozavjetnih kodeksa, ili što iz glagoljske književnosti". ${ }^{4}$ Također, napominje kako mu je prije dvije godine poslao u Zagreb knjigu Bogomilska crkva bosanskih krstjana te da nije dobio potvrdu da ju je Hamm primio i pretpostavlja da je zaplijenjena, pa mu šalje novi primjerak u Ann Arbor jer misli da će ga zanimati. Na kraju navodi kako će u Chicagu Hamm moći pogledati glagoljske kodekse koji se nalaze u Znanstve-

61 AHFP, Mandićeva ostavština, sv. 13, mapa 1, pm. V, (bez oznake folije). Hamm piše Mandiću da je u SAD poveo i četrnaestogodišnjega sina Mladena, kako bi učio engleski jezik.

62 AHFP, Mandićeva ostavština, 13, mapa 1, pm. V, f. 11.

63 AHFP, Mandićeva ostavština, 13, mapa 1, pm. V, f. 11.

64 AHFP, Mandićeva ostavština, 13, mapa 1, pm. V, f. 11. 
noj knjižnici te da povede i sina Mladena kojega će zasigurno, između ostaloga, zanimati i Znanstveni muzej "u kojemu je prikazan razvoj glavnih grana američke industrije s originalnim uzorcima". ${ }^{65}$

Hamm se ponovo javlja Mandiću pismom od 26. rujna 1964., u kojemu najprije navodi kako ga je Mandićevo pismo obradovalo i da mu je drago za Mandićevu godišnjicu, a pogotovo što je primio "Vaš Magnum Opus i raspravu o Bosni i Hercegovini". U ovome pismu Hamm piše:

"morao sam se i moram se diviti i Vašoj energiji i Vašem golemom znanju i dobrom poznavanju historijskih izvora. Kod nas u Beču mi je Vitezić govorio o Vašem djelu, i ja sam ga zamolio da mi napiše prikaz za Wiener slavistisches jahrbuch, i on je obećao, no do mojega odlaska odanle nije mi ga predao: možda nije dospio, pa će to poslije učiniti, a ako ne učini, ili ću zamoliti nekoga iz Osteurop. Instituta, ili ću prikaz sam napisati". ${ }^{66}$

Na Mandićevu zamolbu o pisanju rada o Crkvi bosanskoj za zbornik koji je u njegovu čast planirao izdati Hrvatski povijesni institut $\mathrm{u}$ Rimu ${ }^{67}$ Hamm odgovara:

"O bogumilima ne bi mi lako bilo ovdje nešto napisati, jer nemam uza se ni potrebnih priručnika, ni potrebne rukopise, no vidjet ću što imaju ovdje, a bit ću za desetak dana i u New Yorku, pa ako se ikako bude dalo, smatrat ću se i lično počašćen da sudjelujem u zborniku koji se izdaje Vama u čast". ${ }^{\circ}$

Nadalje Hamm piše: "Kalendar Vašega reda ovdje nije mi poznat pa ne znam kako i što se u njemu piše", te napominje kako ne bi bilo dobro da zbog njega kalendar kasni s izdavanjem pa mu stoga u prilogu šalje obje spomenute pjesme Džore Držića, da se objave bez popratne rasprave "naprosto kao dokaz da su Hrvati već u vrijeme kada se otkrivala Amerika imali ovako lijepe pjesme u Gospinu čast". O tome Hamm piše:

"Ovo je prvi put što se one objavljuju i dosada nigdje nisu štampane i nisu bile poznate, jer se nalaze jedino u rukopisu u arhivu katedrale

65 AHFP, Mandićeva ostavština, 13, mapa 1, pm. V, f. 11.

66 AHFP, Mandićeva ostavština, sv. 13, mapa 1, pm. V, f. 14.

67 Radi se o: Mandićev zbornik. U čast o. dra. Dominika Mandića prigodom njegove 75-godišnjice života, Hrvatski povijesni institut, Rim, 1965.

68 AHFP, Mandićeva ostavština, sv. 13, mapa 1, pm. V, f. 14. 
sv. Patricka u Dublinu u Irskoj. To je dosada jedini potpuni rukopis Držićevih pjesama, a dospio je u Irsku već u XVII vijeku (no bilo je i drugih prijepisa, a jedan je - gotovo sigurno - poznavao i Fr. M. Appendini)". 69

$\mathrm{Na}$ kraju navodi kako još ne zna vrijeme svoga dolaska u Chicago, ali će na vrijeme javiti, te planira ostati najmanje dva dana "jer ima toga mnogo o čem bih želio s Vama govoriti. Tko bi mislio da ćemo se poslije Vaše divne S. M. Mediatrice, koju nikada neću zaboraviti, opet vidjeti ovdje u daleku svijetu". ${ }^{70}$ Pod post scriptum zahvaljuje Mandiću za poslana djela i napominje kako je rukopis već priredio za tisak i predao Akademiji u Zagrebu te da bi trebao izići sljedeće 1965. godine kao posebna knjiga. ${ }^{71}$

Hamm se ponovo javlja Mandiću iz Ann Arbora razglednicom s nadnevkom od 5. listopada 1964. Najprije piše kako je primio knjigu Bogomilska crkva bosanskih krstjana koju čita "sa dubokom zahvalnošću i željom da ih prikažem u svojem "Jahrbuchu", ${ }^{72}$ te kaže da je to "kapitalno djelo bez kojega se neće moći u tim pitanjima!" Obavještava ga također da mu je stiglo i pismo koje je Mandić ranije poslao u Beč, i na njemu mu zahvaljuje, te zaključuje "Kako je lijepo kada se misli ovako 'križaju'". Na kraju navodi kako u petak ide u New York pa će mu uskoro javiti kada dolazi u Chicago. ${ }^{73}$

Pet dana kasnije (10. listopada 1964.) Mandić u pismu upućenom Hammu, nakon što potvrđuje primitak pisma od 26. rujna i "karte" od 5. listopada, izražava zadovoljstvo što Hamm čita njegovu knjigu Bogomilska crkva bosanskih krstjana i što će prikaz ove knjige objaviti u "Vašim izdanjima u Beču". Mandić piše kako je u ovu knjigu uložio mnogo truda te se nada "da će unijeti svjetla u to dosada zamršeno i teško pitanje". Nadalje navodi kako je istraživao "i staro manihejsko krivovjerje i sredovječne katare u zapadnoj Evropi" te smatra da će znanstveni doprinosi i na ovome području "biti korisni i dati novih poticaja za proučavanje tih pitanja i za njihovo konačno rješenje". Spominje kako mu je pri ovome istraživanju od koristi bilo

69 AHFP, Mandićeva ostavština, sv. 13, mapa 1, pm. V, f. 14-15.

70 AHFP, Mandićeva ostavština, sv. 13, mapa 1, pm. V, f. 15.

71 AHFP, Mandićeva ostavština, sv. 13, mapa 1, pm. V, f. 15.

72 Wiener Slavistisches Jahrbuch, Institut für Slawistik der Universität Wien.

73 AHFP, Mandićeva ostavština, sv. 13, mapa 1, pm. V, f. 16. 
"poznavanje raznih jezika i teologije s poviješću raznih kršćanskih sekta, s kojima sam se duže vremena zanimao". ${ }^{74}$

Iz ovoga pisma također saznajemo da je Mandić u privitku Hammu poslao i "moju radnju o govoru Hrvata i Srba, kada su došli na Jug". Napominje kako je to napisao već 1958. godine te slučajno nije postala sastavni dio djela Rasprave i prilozi iz stare hrvatske povijesti. Ovaj rad je u svezi, kako Mandić navodi, s onim "što sam Vam pisao o čakavštini u pismu u Beč". O tome Mandić opširnije ovdje piše:

"Ja dokazujem u "Raspravama", str. 53-60, da su Hrvati došli na Jadran kao poseban izgragjen narod, kako je to zabilježio K. Porfirogenet. To danas prihvaćaju i ozbiljni vanjski povjesničari kao prof. F. Dvornik, B. Grafenauer, i drugi. Ako su Hrvati sa sjevera došli kao posebna skupina, oni su morali imati svoj jezik, kojim su tada govorili. Na osnovu svih povjesnih podataka, valja zaključiti, da je to bila čakavština. Zbog toga bi bilo posebno zanimivo i korisno proučiti čakavštinu kod sjevernih Slavena u današnje doba i u povjesnim spomenicima. To bi mogli Vi u Beču izravno ili preko Vaših veza dati ispitati od mladih učenjaka u njihovim doktorskim radnjama". ${ }^{75}$

Krajem mjeseca (30. listopada 1964.) Hamm ponovo piše Mandiću iz Ann Arbora. U pismu se najprije ispričava što se nije do sada javio te navodi kako je u New Yorku održao predavanje, te išao i u Kanadu pa tek sada može planirati svoj dolazak u Chicago. Naime, on planira 3. prosinca doći u Chicago, pa izražava žalost što ne će moći vidjeti Mandića i čestitati mu rođendan jer taj dan ima tri sata predavanja pa će tek navečer krenuti vlakom. Također piše Mandiću kako je njemu 3. prosinca rođendan, a 4. prosinca će, na poziv sveučilišta u Chicagu, održati slavistima predavanje o hrvatskoj srednjovjekovnoj glagoljskoj poeziji i to "nažalost na engleskom jeziku".

U pismu nadalje iznosi svoje mišljenje o čakavštini te izražava želju kako bi volio na ovu temu s Mandićem više razgovarati. Naime, Mandić mu je već pisao da su Hrvati došli sa sjevera i da je "čakavština bila njihov izvorni jezik", a o tome je Hamm govorio i u Beču i na predavanjima u SAD-u. Pri tome Hamm pojašnjava:

"samo ja na osnovi lingvističkih podataka, ovaj razdio u hrvatskoj povijesti zamišljam ovako: Slaveni su na jug došli ne kao homogena

74 AHFP, Mandićeva ostavština, sv. 13, mapa 1, pm. V, f. 12.

75 AHFP, Mandićeva ostavština, sv. 13, mapa 1, pm. V, f. 12. 
masa nego kao dvije struje, od kojih su jednu sačinjavali čakavci i kajkavci, koji će se poslije - poslije 874., naročito - dalje cjepkati na sjeverniji kajkavski i južniji čakavski dio, a jedni su i drugi bili uže vezani za sjeverozapadne nego sjeveroistočne Slavene. Od ovih drugih potekli su štokavci, koji su se opet poslije podijelili na Bugare, Makedonce i Srbe. Sve se to može dokazivati na osnovi jezičkih podataka i razvitka u jeziku kod jednih i drugih i trećih. O tome sam i objavio jedan opširniji članak u 'Wiener slavistisches Jahrbuch', kojega sam sada urednik i izdavač, pa ću Vam taj članak donijeti kada dođem da Vam čestitam. O svemu tome bi se dalo dugo i mnogo govoriti, pa će mi biti drago, budemo li mogli i o tome izmijeniti misli". ${ }^{76}$

Mandić odgovara Hammu 24. studenoga 1964., izražavajući zadovoljstvo zbog skoroga susreta, te navodeći kako će mu posebno biti drago što će se moći "podulje razgovoriti i o postanku narječja današnjega hrvatskoga jezika".77 $\mathrm{O}$ tome Mandić piše:

"Ta pitanja valja rješavati u najstarijoj periodi na osnovu povjesnih, jer jezičnih spomenika nemamo prije sredine 9. stoljeća. Po najnovijim povjesnim istraživanjima valja razlikovati dvije slavenske selidbe na Balkan: prva od 4. stoljeća po Kristu do početka 7. stoljeća, a druga od 626. do 680. po Kr. Prva je bila Slavena bezimenih, a druga organiziranih naroda Hrvata (god. 626.) Srba (o. god. 635.) i Bugara (god. 680.). Još prije Kristova rogjenja, ili prvih stoljeća iza toga, današnji kajkavci prešli su Karpate i nastanili se na lijevoj obali Dunava. Zbog dugoga i ranoga odijeljenja od drugih Slavena, oni su razvili svoje narječje, koje nema sličnosti s nijednim jezikom sjevernih Slavena, ni zapadnih ni istočnih. Štokavci ikavci došli su s istoka (iz Ukrajine) zajedno s Gotima u 4. stoljeću, a štokavci ekavci iz područja izmegju Dnjepra i Volge u 6. stoljeću. Hrvati, jer su došli kao izgragjen narod, posebna skupina, imali su i svoj jezik kod dolaska na Jug. Taj je morao biti, po mojim povjesnim istraživanjima, čakavski. Da naši razgovori mognu biti plodniji, molit ću Vas, da pročitate u 'Rasprave i prilozi' moje dokaze o dolasku Hrvata kao posebnoga naroda (str. 51-60, 68-76) te o počecima hrvatskoga književnog stvaranja (str. 394-402). O doseljenju Slavena na Balkan pisao sam i u 'Bosna i Hercegovina' sv. I, str. 28-46. Te u Croatian Review II (1959), 46-64. Taj Vam broj šaljem u posebnom omotu". ${ }^{78}$

76 AHFP, Mandićeva ostavština, sv. 13, mapa 1, pm. V, f. 18.

77 AHFP, Mandićeva ostavština, sv. 13, mapa 1, pm. V, f. 19.

78 AHFP, Mandićeva ostavština, sv. 13, mapa 1, pm. V, f. 19. 
Na kraju pisma Mandić navodi kako se nada da je Hamm napisao prilog za Zbornik Hrvatskog povijesnog instituta u Rimu te prikaz njegove knjige Bogomilska crkva bosanskih krstjana te mu unaprijed čestita njegov rođendan i pozdravlja njega i njegova sina Mladena radujući se njihovu dolasku u Chicagu. ${ }^{79}$

U Mandićevoj ostavštini sačuvana je i čestitka (bez datacije) u kojoj Hamm "vraćajući se iz San Francisca" Mandiću čestita njegov rođendan. ${ }^{80}$

Hamm se izgleda krajem godine javlja Mandiću čestitkom (nema datacije), kojom mu čestita Božić i Novu godinu. Pod post scriptum piše kako rukopis u Public Library nije našao i da su mu bibliotekari rekli da se vjerojatno nalazi u drugoj većoj knjižnici. Napominje kako bi za traženje toga rukopisa trebalo dan ili dva a on nema vremena jer se za Božić vraća u Zagreb pa moli Mandića, ako može da zamoli nekoga da pronađe taj rukopis a on bi mu platio honorar za to. ${ }^{81}$

Posljednje sačuvano pismo iz korespondencije Mandić - Hamm datira iz 1965. godine. Naime, na Uskrs ove godine Mandić piše Hammu u Beč, u kojemu najprije njemu i njegovoj obitelji čestita Uskrs. Potom navodi kako je u čikaškim knjižnicama tražio glagoljski kodeks ali ga nije uspio pronaći, te da je pregledao sve popise u knjižnicama u Chicagu i okolici i da se nigdje ne spominje glagoljski kodeks, te pretpostavlja da se nalazi "pod kojim grčkim kodeksom. Tih ima dosta lijep broj". Nadalje spominje kako mu je prije tri-četiri godine jedan profesor poslao signaturu glagoljskoga kodeksa u Chicagu, i ako je uspije pronaći da će mu je poslati. Nakon toga Mandić se interesira na Hammov prilog za zbornik koji se trebao tiskati u Rimu, te napominje kako će slaganje tekstova potrajati i da Hamm za pisanje rada ima vremena do kraja svibnja, s napomenom da mu samo treba na vrijeme javiti hoće li poslati taj rad. Također ga moli da mu pošalje jedan ili dva primjerka prikaza njegove knjige kada iziđe iz tiska, te ga obavještava da će u prvome broju časopisa "Byzantion" izići njegov rad "Dalmatia in the Exarchate of Ravenna".82

79 AHFP, Mandićeva ostavština, sv. 13, mapa 1, pm. V, f. 19.

80 "Mnogopoštovani i dragi Oče! Vraćajući se iz San Francisca želim Vam najsrdačnije svako dobro, dobro zdravlje i svaki Božji blagoslov za Vaš vrijedni rođendan. Vaš odani Josip Hamm". AHFP, Mandićeva ostavština, sv. 13, mapa $1, \mathrm{pm}$. V, f. 17.

81 AHFP, Mandićeva ostavština, sv. 13, mapa 1, pm. V, f. 13.

82 AHFP, Mandićeva ostavština, sv. 13, mapa 1, pm. V, f. 28. Riječ je o članku: Dominik Mandić, "Dalmatia in the Exarchate of Ravenna from the middle of 
Marina Beus - Dijana Korać - Korespondencija...

\section{Zaključak}

Navedena pisma koja su izmijenili Mandić i Hamm pisana su s obostranim velikim poštovanjem, a sadržaj pisama daje uvid u njihove poglede na pojedina pitanja koja su bila predmet zajedničkoga znanstvenog interesa, a posebno promišljanja ove dvojice znanstvenika o Crkvi bosanskoj i čakavštini u Hrvata. Osim izmjenjivanja misli o temama njihova znanstvenoga interesa, evidentna je i uzajamna pomoć u prikupljanju potrebitih izvora i knjiga za njihov znanstvenoistraživački rad, ali i onih koje je Mandić prikupljao za franjevačku knjižnicu u Rimu i Chicagu. Osim toga, u pismima se također spominju i neki tadašnji znanstvenici s kojima su Mandić i Hamm surađivali, kao i neki segmenti iz njihova privatnoga života. Na kraju, možemo zaključiti kako sadržaj korespondencije Mandić - Hamm donosi brojne podatke koji dopunjavaju dosadašnje spoznaje vezane uz njihov znanstveni rad ali i privatni život, a također mogu biti korisni za proučavanje različitih tema iz ovoga razdoblja hrvatske povijesti.

the VI until the middle of the VIII century", u: Byzantion, 34, Bruxelles, 1965., str. 347-374. 
Marina BeUs

University of Mostar

Faculty of Humanities and Social Sciences

Review article

E-mail: marina.beus@ff.sum.ba

DiJana Korać

University of Mostar

Faculty of Humanities and Social Sciences

E-mail: dijana.korac@ff.sum.ba

\section{Correspondence between Dominik Mandic and Josip Hamm in the Archive of the Franciscan Province of Herzegovina}

\section{Summary}

Legacy of one of the most famous Herzegovinian Franciscans, historian Dominik Mandic contains the letters he exchanged with the prominent Croatian Slavist Josip Hamm. There are 18 letters in total and they were written in the period from 1951 to 1956 . Besides the letters, four postcards and three telegrams were also preserved. Letters are mostly one to three pages long and they were written with mutual great respect and friendship. Correspondence Mandic - Hamm gives an insight into opinions of these two scientists on the topics that were the subject of the common scientific interest such as the Bosnian Church and Chakavian dialect in Croatia. Besides exchanging thoughts on certain topics of their scientific interest, it is evident that they helped each other in collecting necessary sources and books for their scientific-research work as well as those Mandic was collecting for the Franciscan library in Rome and Chicago. The letters also mention some scientists of that time, whom Mandic and Hamm were cooperating with, as well as some segments from their private life.

Keywords: Dominik Mandic; Josip Hamm; correspondence; scientific research. 